\title{
Predicting Yield from Differential Agro-ecosystems: The Agripreneurships in Dynamism and Possibilities
}

\author{
Debraj Roy*", Arindam Ghosh, S. K. Achaya, Swagata Ghoshal, \\ Debashis Mazumder and Amitava Biswas
}

\author{
Department of Agricultutal Extension, Bidhan Chandra Krishi Viswavidyalaya, \\ Mohanpur, Nadia, West Bengal, India
}

*Corresponding author

\begin{tabular}{|c|c|}
\hline & A B S T R A C T \\
\hline $\begin{array}{l}\text { K e y w o r d s } \\
\text { Agro-economical, } \\
\text { Challenges, Income, } \\
\text { Poultry, } \\
\text { Productivity, Rice, } \\
\text { Socio-personal, } \\
\text { Techno-managerial } \\
\text { characters }\end{array}$ & $\begin{array}{l}\text { The study was conducted on Rice and Poultry entrepreneurs in Memari-1 block, Purba } \\
\text { Barddhaman district of West Bengal, India. This has been conducted to assess their socio- } \\
\text { personal, agro-economical and techno-managerial skills. Several entrepreneurial aspects } \\
\text { are considered in this study to portrait a well discernible picture of their entrepreneurship. } \\
\text { The acquired data and other information was critically examined with several statistical } \\
\text { tools like range, mean, standard deviation, variance, correlation coefficient, stepwise } \\
\text { regression analysis, multiple regression analysis, factor analysis and cluster analysis. Total } \\
18 \text { variables were considered for the study in which } 15 \text { of them are independent variables } \\
\text { and } 3 \text { of them dependent variables. Correlation coefficient is significant for the }\end{array}$ \\
\hline Article Info & ise Regression analysis several satisfactory conclusions were drawn for the study \\
\hline $\begin{array}{l}\text { Accepted: } \\
\text { 26 September } 2020 \\
\text { Available Online: } \\
10 \text { October } 2020 \\
\end{array}$ & $\begin{array}{l}\text { which well described the current neo agricultural scenario in rural Bengal. It has been } \\
\text { revealed that the smaller is the size of the economic land the higher has been the yield. } \\
\text { This is due to the higher concentration focus on the small piece of the land, high intensity } \\
\text { monitoring, and auditing during the entire phase of production. Factor analysis was done } \\
\text { to strategically conglomerate the variables into marker variables. }\end{array}$ \\
\hline
\end{tabular}

\section{Introduction}

More than half of the population in India is related to agriculture and its allied sectors for their survival and livelihood. Agricultural cooperatives are important rural organizations supporting livelihood development and poverty reduction (Kindie Getnet et al., 2012). In this neo-agricultural era India is experiencing a rapid change in population curve as well as in technological intervention with human behavior. Micro-enterprises are the keys to generate employment opportunities as well as income earning avenues to both landless, women and landholding people. Therefore, the poverty alleviation in semi-arid regions requires a greater understanding of the interactions of agriculture and allied enterprises and their implications for the household economy. This paper synthesizes the available evidence on agriculture and allied enterprises in watershed 
development areas and how policy should address the issue to balance between agriculture and micro- enterprises promoted by watershed development programs (Anantha et al., 2009). To coup up with the increasing demand and changing behavior the advancement in agriculture is also needed. We all know how much Rice means as a means of food and as well as a commodity for availing foreign exchange in India. Same as in case of Poultry industry India is enjoying a rapid growth and is about to become self sufficient in poultry products.

Family poultry production (FP), which is still important in low-income food-deficit countries, is an appropriate system to supply the fast-growing human population with high quality protein. It was found that family poultry farming was chosen by $100 \%$ farmers as subsidiary occupation. Small farmers earned an income of Tk. 3705.95 per year as net return from family poultry farming and it generated on average 53.23 working man days per year as employment especially for women. As regards of livelihood improvement, family poultry farming changed food habit, increased knowledge and skill, savings, social status, recreational facility, improved food nutritional condition, family health and sanitation and enhanced women empowerment (Md. Shahidul Islam et al., 2015). It can also provide additional income to the generally resource-poor small farmers, especially women. Although requiring low levels of inputs, FP contributes significantly to food security, poverty alleviation and ecologically sound management of natural resources (Fallou Gueye, 2002). The poultry industry in India has emerged as the most dynamic and rapidly expanding segment of livestock economy as evident from the production level touching about 40 billion eggs and 1 billion broilers with a compound annual growth rate of 8 percent and 15 percent respectively. Egg consumption was found to grow at a much faster pace than poultry meat with the rise in income and nearly triple by 2020 . Similarly, average per capita poultry meat consumption was found to increase from 0.69 to $1.28 \mathrm{~kg}$. Overall study reports the total egg consumption to increase from 687 million $\mathrm{kg}$ to 1674 million $\mathrm{kg}$ (Samarendu Mohanty et al., 2003). What was once started as a novelty in the 1970 's - egg and broiler production - has now turned out to be a highly organized agri-business. But in spite of all these developments and relatively competitive value of the Indian poultry products (especially egg), the relative position of India in the world trade of poultry products is not so encouraging. Indian poultry industry has been growing at annual varying rates of 815 percent and this growth in the past few decades made India 4th largest producer of eggs and 5th largest producer of poultry broilers. Poultry products account for more than $75 \%$ of the non-vegetarian items consumed in India. A national support to strengthen the poultry production is required in the area of finance and input. This is essential for substantial improvements in the contribution of the enterprise to household food production and economic well being of poor farmers. However, a critical gap is still needs to be filled by the research extension outfit in combining the technical and socioeconomic aspects of poultry production in order to boost country's egg and meat production (Adebayo et al., 2017).

Same as the Rice is a staple food for more than half of the world population and in Asia alone more than 2000 million people obtain 60-70 percent of their calories from rice and its products Rice cultivation is the principal activity and source of income for millions of households around the globe, and several countries of Asia and Africa are highly dependent on rice as a source of foreign exchange earnings and government revenue. Per hectare cost of cultivation is about 10 per 
cent lower in SRI than the conventional method. The logit framework has indicated that age, farm size, income of the farm, number of earners in the family and number of contacts with extension agencies are positive and highly influence the adoption behavior of the farmers. Lacks of skilled labour, awareness, training on new technology and experience have been opined as the main problems in adoption of this technology by the farmers. To sum-up, farmers have been vastly benefited by SRI technology and it has helped them in their socio-economic upliftment. The adoption of SRI technique has helped increase the rice production without increasing the area under its cultivation and has proved to serve as an alternative method for rice cultivation (Devi et al., 2009). In Asia, more than $80 \%$ of the people live on rice, and their primary food security is entirely dependent on the volume of rice produced in this part of the world. However, rice production increases are now lagging behind population growth.

Overall, the total global rice is declining gradually even with the extensive use of the modern varieties such as high yielding and hybrid varieties. Over 90 per cent of the world's rice is produced and consumed in the Asian region comprising 80 per cent of the world's production and consumption. Growth in Asian population (1.8\% per annum) in this region means an increase on demand for rice. Although the net availability of food grains has increased in 2013 at 229 million tones, but there will be a shortage of rice due to increased domestic needs coupled with export demand for rice in future.

The growth rates of food grain production in India have declined to 2 per cent during the period 1996-2008 as compared 1986-97 and rice production in India is questionable on economic and ecological grounds. It was projected that India will face a shortage of food in the future where prevalence of undernourishment of 12.7 per cent in Asia. Under these circumstances, increasing rice production is an imperative to sustain selfsufficiency and food security in India. Policies that would enhance farmers access to land, fertilizers, improved seeds, herbicides and labour; coupled with strategies for substituting women's time on production activities for non-entrepreneurial activities would likely enhance rice production and gender equity among rice farmers (Ayoola et al., 2011).

In spite of a spectacular growth in the poultry sector during the past two decades, a huge gap exists between availability and requirement of poultry products. The main challenges of the industry include lack of slaughter facilities for small-scale broiler producers, unorganized supply of poor quality feeds and stock, delayed allocation of land by the Land Boards and inadequate extension service. To overcome these constraints, government intervention is required.

Despite these constraints, the industry has grown and continues to grow robustly as epitomized by high per capita consumption values (Moreki, 2010). Increase in population growth, changing life-style, shifting of food habits, rapid urbanization, increased per capita income, awareness about health care, etc. are contributing towards rising demand of poultry products. Therefore, to meet the domestic requirement, there is a need of further study of poultry farming in Indian context.

On the other side to understand the main problems that are faced by the rice farmers, we have to observe and study the ongoing situation in paddy farming. The most important of these factors are: limited returns as we approach the yield potential of the high yielding varieties, declining productivity in 
intensive rice production systems, pressures from abiotic and biotic stresses, low returns in developing countries, increasing production costs in industrialized countries, and increasing public concern for the protection of environmental resources (N.V Nguyen et al., 2006). To enhance more export quantity, quality and export earnings in the future, we need to know how about the constraints faced in rice export at different stages, in different levels, and different stakeholders involving in the exporting process to find out the suitable solutions for overcoming the constraints.

The main constraints towards farmers are focused in three problems viz. agro-ecological constraints, technological constraints and socio-economic constraints for understanding the real situations in rice production.

The objective of the study was to elucidate the distributive characters of operating farms in the selected locale of the study, to identify and estimate the yield and as the dependent variable, a score of agro-economic, sociopersonal and techno-managerial variables, to estimate and analyze the nature and direction of interaction among the independent and dependent variables, to delineate a micro level policy, the constrain of the operating farms can be analyzed and intervention programmes can be operationally described.

\section{Materials and Methods}

In this chapter research methodology is described to make this study understandable. This chapter includes methods and techniques which were utilized to design it, collect the information as well as the analysis of data to reveal the truth and formulation of theories. This is made under six sub-heads particulars.

Locale of Research

Sampling design

Pilot study
Variables and their measurements

Methods and data collection

Statistical tools for data analysis

\section{Locale of Research}

The ongoing study was conducted in Purba Barddhaman district. The village Rasulpur of Memari-1 blocks in the mentioned district of West Bengal state was selected for the study.

The researcher's close proximity with respect to area, people, officials and local factors.

The ample opportunity to generate relevant data due to close familiarity of the researcher. Existing responsive respondents of the studied area.

Prevalence of the characters was under observation.

Easy accessibility of the area.

\section{Sampling Design}

Selection of state, district, block and village is made by purposive sampling technique and incase of selection of respondents simple random sampling technique was taken up. Total 50 respondents have been selected for the study.

\section{Pilot Study}

Pilot study was conducted to understand the area, its people, institution, communication and extension system and the knowledge, perception and attitude of the people towards farm entrepreneurship concept.

\section{Variables and their measurements}

After pilot study and consulting the advisory committee a list of variables was prepared. On the basis of the selected variables a schedule was prepared. 


\section{Methods of data collection}

\section{Preparation of interview schedule}

On the basis of the findings of pilot study interview schedule was prepared with the help of review literature and by the assistance of chairman of Advisory Committee. The schedule consists of Agro-economic, sociopersonal and techno-managerial.

\section{Pre testing of interview schedule}

Main objective of this performance is to detect the discrepancies that have emerged and to eliminate them after necessary modification in the schedule. The individuals who responded in pretesting have been excluded in the final sample for the study.

\section{Techniques of field data collection}

The respondents were personally interviewed during festival vacation (Durga puja). The recent situation of COVID-19 pandemic within India hampers the conducted study as well as the plan of work. In spite of that we have tried our best to make this study successful. Local language (Bengali) was used to retrieve the information from the respondent. The entries were done by the student investigator himself at the time of interview.

\section{Results and Discussion}

\section{Coefficient of correlation between yield $\left(\mathrm{y}_{1}\right)$ and 15 independent variables}

Figure 1 presents the coefficient of correlation between yield and 15 independent variables. It has been found that, except the variable market interaction $\left(\mathrm{x}_{10}\right)$; all other variables have got significant contribution to yield. So, this implies that that the selections of variables are extremely relevant and their impact on yield is significant except the variable Market interaction $\left(\mathrm{x}_{10}\right)$.

Multiple regression analysis of yield $\left(\mathrm{y}_{1}\right)$ and 15 causal variables

Table 1 presents the multiple regression analysis of yield $\left(\mathrm{y}_{1}\right)$ and 15 causal variables. This implies that the table having these 15 causal variables operated together to explain 97.30 percent of variance in yield. So, the functional impact of all these 15 causal variables on the consequent variable yield $\left(\mathrm{y}_{1}\right)$ is well discernible.

Stepwise regression analysis: Yield $\left(\mathrm{y}_{1}\right)$ Vs. 15 Causal Variables

The following variables: Economic land $\left(\mathrm{x}_{7}\right)$, Education $\left(\mathrm{x}_{2}\right)$, Fuel consumption $\left(\mathrm{x}_{9}\right)$, innovation proneness ( $\left.\mathrm{x}_{13}\right)$, Market interaction $\left(\mathrm{x}_{10}\right)$ have been retained at the last stage and has contributed together 96.50 percent of variance embedded in the consequent variable, Yield $\left(\mathrm{y}_{1}\right)$. Except these 6 variables the rest 9 causal variables impact on Yield $\left(\mathrm{y}_{1}\right)$ is insignificant and minuscule. Almost 99.17 percent of variance has been contributed by these 6 causal variables. So the 6 causal variables have contributed the entirety of total contribution in predicting the Yield $\left(\mathrm{y}_{1}\right)$. From the below sited figure, it has been revealed that the smaller is the size of the economic land the higher has been the yield. This is due to the higher concentration focus on the small piece of the land, high intensity monitoring, and auditing during the entire phase of production. The small entrepreneurs in this part of India are very much involved directly in entrepreneurial management with production management and this has been very much successful for the small but consolidated holdings. It has also been found that the higher is the education level the higher has been the yield, this is due to the situation where neo 
agricultural atmosphere is coming up in rural Bengal, education has a tremendous role to contribute and exactly what it is happening here. It is not that they are only educated in formal or institutional education, they have exposed themselves in different skill training organized by private and government organization. So there is a significant blend between formal and informal education amongst them that's why in west Bengal for the past couple of decades the spark of poultry and value added rice cultivation have gone up like anything. Any kind of entrepreneurial expansion especially in new age rural social ecology in rural Bengal needs electrification and communication. It is well discernible that with the proper transportation facilities, market link extension system and electrification, there has been a wide scale spread of small entrepreneurship like poultry and value added rice industry like anything. One of the important indicators for efficient entrepreneurship, the fuel use efficiency is one of the most important indicators. It has found that fuel consumption has gone down because of improvement efficiency. Innovation is the prime mover for any enterprise to build up to grow and to harvest success. It is well been observed that in case of rice and poultry entrepreneurs have skilled up their innovation proneness and they are far ahead of other agricultural-entrepreneurs in the adjoin areas. As should have been this respondents have recorded higher market interaction which have been reflected in their yield. The higher is the market interaction, the higher would be the demand in the market and logically he will be motivated to go for higher yield (Table 2 and 3 ).

Table.1 List of independent variables

\begin{tabular}{|c|l|c|c|}
\hline SI No. & \multicolumn{1}{|c|}{ Variables } & Notation & Score \\
\hline $\mathbf{1}$ & Age & $\mathrm{x}_{1}$ & Chronological Age \\
\hline $\mathbf{2}$ & Education & $\mathrm{x}_{2}$ & Years of schooling \\
\hline $\mathbf{3}$ & Family size & $\mathrm{x}_{3}$ & No of family member \\
\hline $\mathbf{4}$ & Income & $\mathrm{x}_{4}$ & Family income/Year \\
\hline $\mathbf{5}$ & Expenditure & $\mathrm{x}_{5}$ & Family Expenditure/ Year \\
\hline $\mathbf{6}$ & Homestead land & $\mathrm{x}_{6}$ & Total land holding \\
\hline $\mathbf{7}$ & Economic Land & $\mathrm{x}_{7}$ & Economic land \\
\hline $\mathbf{8}$ & Electricity consumption & $\mathrm{x}_{8}$ & Rs. Per month \\
\hline $\mathbf{9}$ & Fuel consumption & $\mathrm{x}_{9}$ & Rs. Per month \\
\hline $\mathbf{1 0}$ & Market interaction & $\mathrm{x}_{10}$ & No of visit per month \\
\hline $\mathbf{1 1}$ & Group interaction & $\mathrm{x}_{11}$ & $1-10$ scale \\
\hline $\mathbf{1 2}$ & Distance Matrix & $\mathrm{x}_{12}$ & $1-10$ scale \\
\hline $\mathbf{1 3}$ & Innovation Proneness & $\mathrm{x}_{13}$ & $1-10$ scale \\
\hline $\mathbf{1 4}$ & Market Orientation & $\mathrm{x}_{14}$ & $1-10$ scale \\
\hline $\mathbf{1 5}$ & Risk Orientation & $\mathrm{x}_{15}$ & $1-10$ scale \\
\hline
\end{tabular}


Table.2 List of dependent variable per Hectare)

Table.3 Presents the multiple regression analysis of Yield $\left(\mathrm{y}_{1}\right)$ and 15 causal variables

\begin{tabular}{|l|l|c|c|c|c|}
\hline Sl. No. & Variables & Reg. Coef. B & S.E. B & Beta & t Value \\
\hline $\mathbf{1}$ & Age $\left(\mathrm{x}_{1}\right)$ & .005 & .047 & .005 & .104 \\
\hline $\mathbf{2}$ & Education $\left(\mathrm{x}_{2}\right)$ & .193 & .066 & .193 & 2.924 \\
\hline $\mathbf{3}$ & Family size $\left(\mathrm{x}_{3}\right)$ & .036 & .041 & .036 & .866 \\
\hline $\mathbf{4}$ & Income $\left(\mathrm{x}_{4}\right)$ & .144 & .197 & .144 & .731 \\
\hline $\mathbf{5}$ & Expenditure $\left(\mathrm{x}_{5}\right)$ & -.042 & .145 & -.042 & -.291 \\
\hline $\mathbf{6}$ & Homestead land $\left(\mathrm{x}_{6}\right)$ & .004 & .095 & .004 & .038 \\
\hline $\mathbf{7}$ & Economic land $\left(\mathrm{x}_{7}\right)$ & -.627 & .068 & -.627 & -9.199 \\
\hline $\mathbf{8}$ & Electricity consumption $\left(\mathrm{x}_{8}\right)$ & .186 & .107 & .186 & 1.743 \\
\hline $\mathbf{9}$ & Fuel consumption $\left(\mathrm{x}_{9}\right)$ & -.087 & .083 & -.087 & -1.045 \\
\hline $\mathbf{1 0}$ & Market interaction $\left(\mathrm{x}_{10}\right)$ & .066 & .041 & .066 & 1.618 \\
\hline $\mathbf{1 1}$ & Group interaction $\left(\mathrm{x}_{11}\right)$ & .107 & .088 & .107 & 1.218 \\
\hline $\mathbf{1 2}$ & Distant matrix $\left(\mathrm{x}_{12}\right)$ & .065 & .056 & .065 & 1.161 \\
\hline $\mathbf{1 3}$ & Innovation proneness $\left(\mathrm{x}_{13}\right)$ & .112 & .051 & .112 & 2.196 \\
\hline $\mathbf{1 4}$ & Market orientation $\left(\mathrm{x}_{14}\right)$ & .065 & .041 & .065 & 1.583 \\
\hline $\mathbf{1 5}$ & Risk orientation $\left(\mathrm{x}_{15}\right)$ & -.038 & .041 & -.038 & -.928 \\
\hline
\end{tabular}

R square: $97.30 \%$;

The standard error of the estimate: 0.197

Fig.1 Correlation coefficient of Yield $\left(\mathrm{y}_{1}\right)$ and 15 independent variables

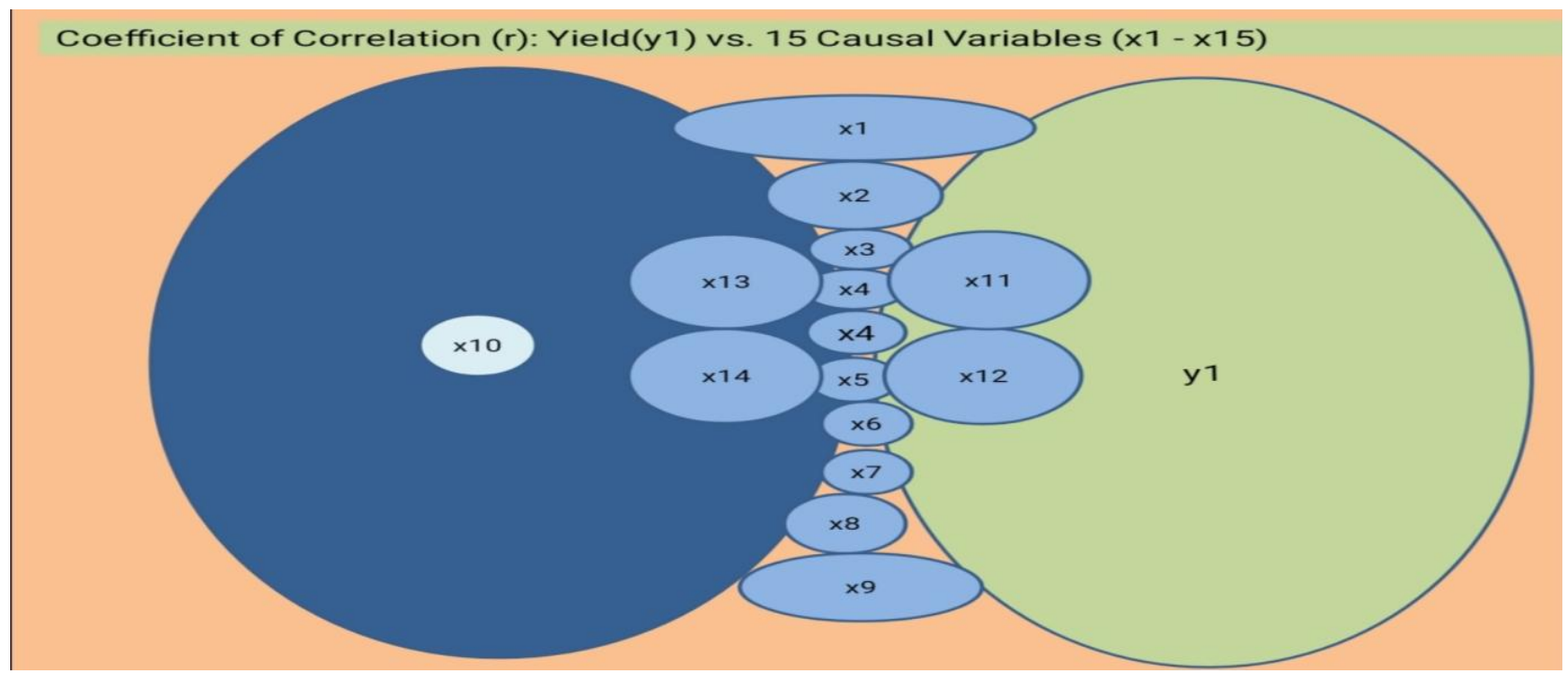


Fig.2 Stepwise regression analysis of Yield $\left(\mathrm{y}_{1}\right)$ and 15 independent variables

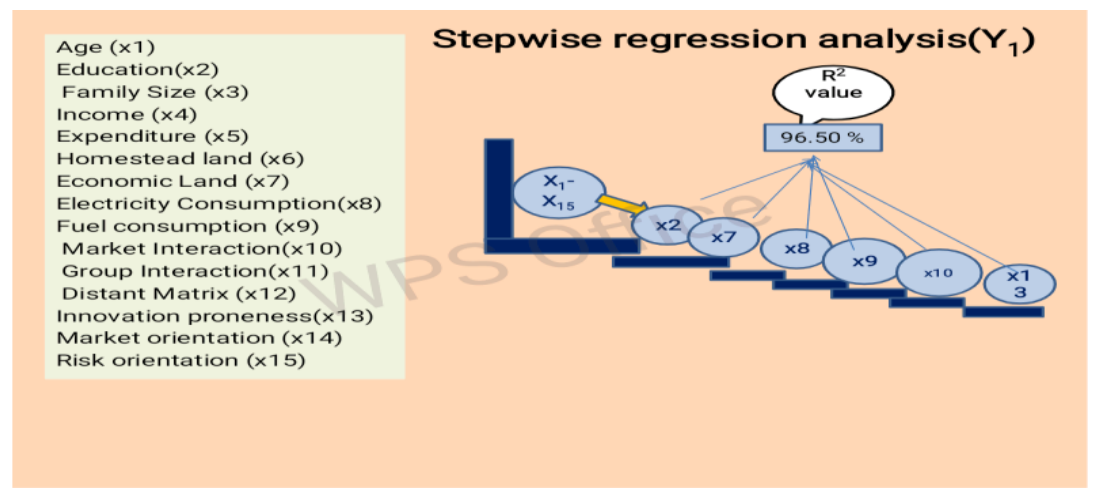

Fig.3 Path analysis of Yield $\left(\mathrm{y}_{1}\right)$ and 15 independent variables

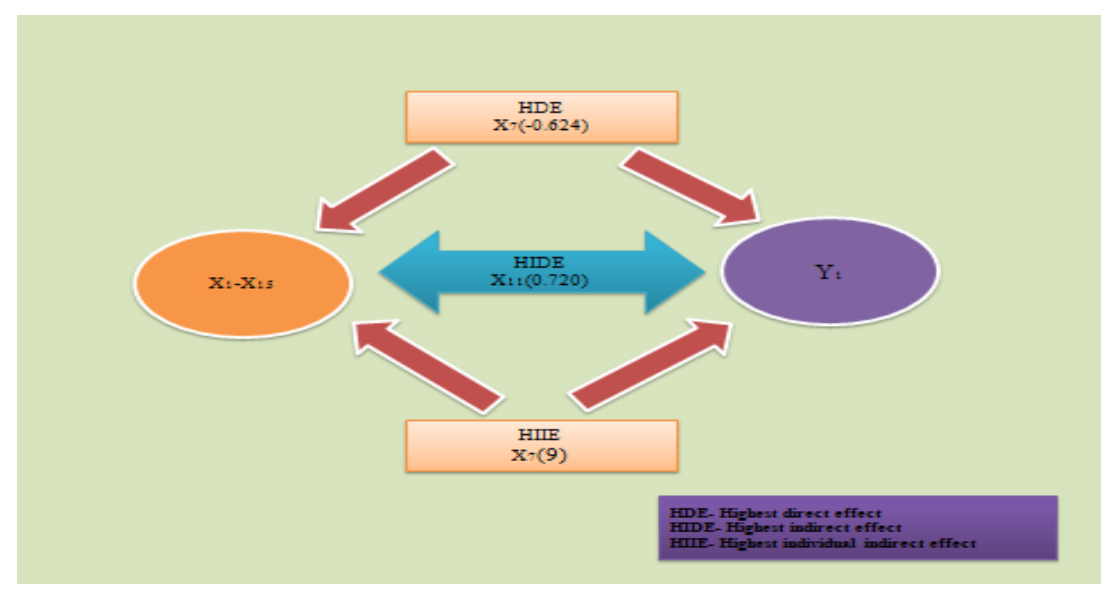

Path Analysis: decomposition of total effect into direct, indirect and residual effect: Yield (y1) and 15 independent variables

It has been recorded that Economic land $\left(\mathrm{x}_{7}\right)$ has the highest direct effect. It has an overwhelming impact on Yield $\left(\mathrm{y}_{1}\right)$ and it is a strong determinant of yield level and behavior. The higher is the economic land the higher would be his negotiability with the market and more option left with him. Entrepreneurship is a collective endeavor, may be initiated individually but he or she has to undergo collective interaction for a successive entrepreneurship. That is why this has been recorded highest indirect effect. The Variable Economic land $\left(\mathrm{x}_{7}\right)$ has routed the highest indirect effect to nine variables to ultimately characterize the consequent variable Yield $\left(\mathrm{y}_{1}\right)$. So this variable must be focused with high importance with the variable Group interaction $\left(\mathrm{x}_{11}\right)$. Residual effect being 0.027 it can be concluded that with the combination of 15 exogenous variables only 2.7 percent of variance could not be explained.

In conclusion the dynamics of entrepreneurship, here in case of Rice and Poultry enterprises, are dominantly relying with the entrepreneurs' behavioral character, the group interaction they are experiencing, the economic land they are possessing, the electricity consumption level, and the fuel use efficiency and with innovation proneness and market interaction. While the entrepreneur 
ecology is basically a composition of human behavior and decision making process, resource endowment, communicability and interaction with the surroundings, it is extremely important that to build up successful entrepreneurship, Land is still an important factor and at the same time innovation proneness and market interaction are coming up with swashbuckling impact. But the most interesting observation is that the rural entrepreneurship is successful when group interaction plays a significant role. it has been revealed that the smaller is the size of the economic land the higher has been the yield. This is due to the higher concentration focus on the small piece of the land, high intensity monitoring, and auditing during the entire phase of production. The small entrepreneurs in this part of India are very much involved directly in entrepreneurial management with production management and this has been very much successful for the small but consolidated holdings. It has also been found that the higher is the education level the higher has been the yield, this is due to the situation where neo agricultural atmosphere is coming up in rural Bengal, education has a tremendous role to contribute and exactly what it is happening here. It is not that they are only educated in formal or institutional education, they have exposed themselves in different skill training organized by private and government organization. So there is a significant blend between formal and informal education amongst them that's why in west Bengal for the past couple of decades the spark of poultry and value added rice cultivation have gone up like anything. Any kind of entrepreneurial expansion especially in new age rural social ecology in rural Bengal needs electrification and communication. It is well discernible that with the proper transportation facilities, market link extension system and electrification, there has been a wide scale spread of small entrepreneurship like poultry and value added rice industry like anything. One of the important indicators for efficient entrepreneurship, the fuel use efficiency is one of the most important indicators. It has found that fuel consumption has gone down because of improvement efficiency. Innovation is the prime mover for any enterprise to build up to grow and to harvest success. It is well been observed that in case of rice and poultry entrepreneurs have skilled up their innovation proneness and they are far ahead of other agricultural-entrepreneurs in the adjoin areas. As should have been this respondents have recorded higher market interaction which have been reflected in their yield. The higher is the market interaction, the higher would be the demand in the market and logically farmers will be motivated to go for higher yield.

\section{Competing interest disclaimer}

Authors have declared that no competing interests exist. The products used for this research are commonly and predominantly use products in our area of research and country. There is absolutely no conflict of interest between the authors and producers of the products because we do not intend to use these products as an avenue for any litigation but for the advancement of knowledge. Also, the research was not funded by the producing company rather it was funded by personal efforts of the authors.

\section{References}

Adebayo O.O, Adeola R.G.(2017). Socioeconomic factors affecting Poultry farmers in Ejigbo Local Government area of Osun state. Journal of Human Ecology. 18(1):39-41. https://doi.org/10.1080/09709274.2005. 11905804

Anantha KH, Wani SP \& Sreedevi TK. (2009). Agricultural and allied Micro- 
enterprise for livelihood opportunities. International Crop research institute for the Semi-Arid Tropics (ICRISAT).

Ayoola J.B, Dangbegnon C, Daudu CK, Mando A, Kudi TM, Amapu I.Y, Adeosun J.O, Ezui K.S. (2011). SocioEconomic factors influencing rice production among male and female farmers in Northern Guinea Savanna Nigeria: Lesson for promoting gender equity in action Research. Agriculture and Biology journal of North America.Doi10.5251/abjna.2011.2.6.1010.1014

Devi K.S, Ponnarasi T. (2009). An Economic Analysis of Modern Rice Production Technology and its Adoption Behaviour in Tamil Nadu. Agricultural Economics Research Review. 22.

Getnet K and Anullo T. (2012). Agricultural Cooperatives and rural livelihoods: Evidence from Ethiopia. Annals of public and cooperative Economics. 8(2):181-18

Gueye EF.2002. Employment and income generation through family poultry in low income food deficit countries. World Poultry Science Journal. 58(4): 541-557. DOI-10.1079/WPS20020039.

Islam Md.S, Begum IA, Kausar AKMG \& Hossain R( 2015). Livelihood improvement of small farmers through family poultry in Bangladesh. International Journal of Business, Management and Social Research. 1(2): 61-70.

DOI-

10.18801/ijiomsr.010215.07.

Mohanty, Samarendu, Rajendran K. (2003). 2020 vision for Indian Poultry Industry. International journal of Poultry Science.2 (2):139-143.

Moreki JC.2010. Opportunities and Challenges for the Botswana poultry industry in the $21^{\text {st }}$ Century: A review. Livestock Research for Rural Development. 22(5)

Nguyen N.V, Ferrero A, (2006). Meeting the Challenges of Global Rice Production. Paddy and Water Environment.4:1-9

\section{How to cite this article:}

Debraj Roy, Arindam Ghosh, S. K. Achaya, Swagata Ghoshal, Debashis Mazumder and Amitava Biswas. 2020. Predicting Yield from Differential Agro-ecosystems: The Agripreneurships in Dynamism and Possibilities. Int.J.Curr.Microbiol.App.Sci. 9(10): 32313240. doi: https://doi.org/10.20546/ijcmas.2020.910.386 